\title{
Effect of Corporate Social Responsibility on Business Sustainability: The Dual Mediation
}

\author{
I Wayan Gde Sarmawa ${ }^{1^{*}}$, Ida Ayu Oka Martini ${ }^{2}$, Ida Ayu Putu Widani Sugianingrat ${ }^{3}$ \\ ${ }^{1}$ Faculty of Economics and Business, Warmadewa University, Bali, Indonesia, wayangdesarmawa@gmail.com \\ ${ }^{2}$ Faculty of Economics and Business, Universitas Pendidikan Nasional, Bali, Indonesia, dy.oka.martini@gmail.com \\ ${ }^{3}$ Faculty of Economics, Business and Tourism, Universitas Hindu Indonesia, Bali, Indonesia, \\ widanidayu147@gmail.com \\ *corresponding author
}

\begin{abstract}
Companies are constantly trying to maintain customer trust and loyalty in an effort to preserve business sustainability. Implementing environmental concerns in the form of Corporate Social Responsibility (CSR) is expected to achieve both of these aims. This study aims to analyze the roles of CSR, customer trust, and customer loyalty in business sustainability. Questionnaires were filled by 10 customers from each of 100 Rural Banks spread over 9 districts/cities in Bali, Indonesia. Data analysis was performed with SmartPLS 3.3.2 software. The research found that CSR, customer trust, and customer loyalty have a significant impact on business sustainability. The results also found that customer trust and customer loyalty function as mediation in the relationship between CSR and business sustainability.
\end{abstract}

Keywords: Corporate Social Responsibility, customer trust, customer loyalty, business sustainability

\section{Pengaruh Tanggung Jawab Sosial Perusahaan terhadap Keberlanjutan Bisnis: Mediasi Ganda}

\begin{abstract}
Abstrak
Perusahaan senantiasa berusaha menjaga kepercayaan dan loyalitas pelanggan dalam upaya menjaga keberlangsungan bisnis. Implementasi kepedulian lingkungan dalam bentuk Corporate Social Responsibility (CSR) diharapkan dapat mencapai kedua tujuan tersebut. Penelitian ini bertujuan untuk menganalisis peran CSR, kepercayaan pelanggan, dan loyalitas pelanggan dalam keberlanjutan bisnis. Kuesioner diisi oleh 10 nasabah dari masing-masing 100 BPR yang tersebar di 9 kabupaten/kota di Bali, Indonesia. Analisis data dilakukan dengan software SmartPLS 3.3.2. Hasil penelitian menemukan bahwa CSR, kepercayaan pelanggan, dan loyalitas pelanggan memiliki pengaruh yang signifikan terhadap keberlangsungan bisnis. Hasil penelitian juga menemukan bahwa kepercayaan pelanggan dan loyalitas pelanggan berfungsi sebagai mediasi dalam hubungan antara CSR dan keberlanjutan bisnis.
\end{abstract}

Kata kunci: Tanggung Jawab Sosial Perusahaan, kepercayaan pelanggan, loyalitas pelanggan, keberlangsungan usaha

\section{INTRODUCTION}

Sustainability is an integral business target constantly strived toward by company managers. Growth is also sought after; growth in general and growth across business periods. Company leaders apply various strategies to achieve these attributes for their businesses, including the development and maintenance of customer trust. Certain businesses, such as banks and other financial institutions, mostly aim to develop robust customer loyalty to prevent customers being easily persuaded to turn to competing companies. 
Rural Banks were chosen as the object of this research because from 2016 to 2019, three were unable to survive, indicating that Rural Bank business sustainability decreased from year to year. Studies have proven that customer trust and loyalty can maintain the sustainability of an institution/company/organization. The results of Ong and Zien's (2015) research on a number of SMEs in Malaysia found that their sustainability was largely determined by the level of trust that their customers held. Similar results were also found in research conducted by Nguyen et al. (2013) and Upamannyu et al. (2015). Kang and Hustvedt (2014) stated that trust is the key to building a market; an opinion reinforced by Zieni et al. (2017), who concluded that trust can lead to social sustainability.

The level of customer trust in a company or organization is shown through customers' intent in their relation (loyalty) to the company. The more often someone uses a company's products, the higher their loyalty. Higher customer loyalty can be a direct consequence of higher trust in the company's products (Brilliant \& Achyar, 2013). Taoketa (2018) states that in the sustainable marketing of a product, customer trust ranks first in importance for marketing considerations. Hossain (2019) also agrees that trust is a dominant factor in shaping customer loyalty. This opinion is also in line with the results of research conducted by Leninkumar (2017), which found that customer trust had a significant positive effect on customer loyalty in commercial banks in Sri Lanka. The results of other studies found a significant positive influence between customer trust and customer loyalty, namely Nur (2012), Sarwar et al. (2012), Utami (2015), Leninkumar (2017), Trini and Salim (2018), and Widodo and Murwatiningsih (2019). On the other hand, a study conducted by Setiawan and Sayuti (2017) found that customer trust had no significant effect on customer loyalty.

Several studies have proven that loyalty is important for company success, profitability, and long-term sustainability (Strenitzerová \& Gaňa, 2018). Aslam et al. (2020) stated that loyalty is a key factor in obtaining benefits and organizational growth in the long term. Additionally, Ong and Zien (2015) stated that customer trust and loyalty are very important to ensure sustainable income and profits as well as overall business sustainability in the long term.

In addition to these statements, a number of studies conclude that a company's social concern for the community (often referred to as Corporate Social Responsibility or CSR) can foster customer trust and loyalty (Azmat \& Ha, 2013; Choi \& La, 2013; Vlachos et al., 2009). Cegliński and Wiśniewska (2016) reinforce this idea, stating that CSR activities carried out by companies can be a source of many benefits that can increase customer confidence and the company's competitive advantage.

Málovics et al. (2008) stated that CSR is becoming increasingly important in today's business life, especially for its contribution to business sustainability. Similar opinions were also expressed by Kitthananan (2010), Teodorescu and Ionescu (2014), Mourougan (2015), and Grigoris (2016). Lu et al. (2020) took a granular approach and found that each of the dimensions of CSR separately affect elements of competitiveness.

A study conducted by Leninkumar (2017) found that customer trust had a significant positive effect on customer loyalty in commercial banks in Sri Lanka. This approach is 
integral to banks as they must constantly work to maintain customer loyalty and customer trust. The researcher thus aims to confirm the impact of CSR on customer trust, customer loyalty, and business sustainability on the declining Rural Bank network in Indonesia. Dual mediations of customer trust and customer loyalty are considered the novelty of this study.

\section{Theoretical Review, Previous Research, and Hypothesis}

\section{Business Sustainability}

Company leaders have a large responsibility in efforts to maintain business sustainability (Gonzalez et al., 2013). Business sustainability can be defined as a company's ability to utilize resources to survive various situations (Szekely \& Knirsch, 2005). Schaltegger and Burritt (2005) stated that business sustainability is a broad concept consisting of various characteristics, especially those related to the contextual integration of economic, environmental, and social aspects.

The sustainability of a company is determined by complex factors, both internal and external. Internal factors that can affect business sustainability include support for corporate resources including human resources and leadership patterns (Sarmawa et al. 2020), corporate governance, and environmental/corporate climate management. External factors include customer trust and loyalty, socio-economic conditions, and government participation.

\section{Corporate Social Responsibility (CSR)}

The definition often cited in the research is that from Carroll (1979): CSR is the responsibility of the company towards the environment and society and includes elements of economy, law, ethics, and wisdom. Fontaine (2013) states that CSR is a strategy for how to align business values and behavior with the expectations and needs of stakeholders; not only customers and investors, but also employees, suppliers, communities, regulators, special interest groups, and society as a whole.

According to Mourougan (2015), CSR is understood as the way companies integrate social, environmental, and economic problems into their values, culture, decision-making, strategies, and operations in a transparent and accountable manner to build better practices within the company, in-turn creating wealth and improving society. CSR is a company initiative to assess and take responsibility for the company's impact on the environment and its impact on social welfare (Teodorescu \& Ionescu, 2014).

CSR is seen as having an important role in business sustainability (Málovics et al., 2008). CSR is also considered to play an important role in gaining a sustainable advantage over competitors, gaining profits, and improving business dealings with customers (Afridi et al, 2018). It is a business model that encourages business contributions to sustainable development, and creating a balance between economic interests, environmental, and social needs (Behringer \& Szegedi, 2016). According to Grigoris (2016), CSR has become a successful way to gain a competitive advantage and ensure the capacity for long-term value. According to Kitthananan (2010) and Teodorescu and Ionescu (2014), CSR is a 
business strategy to achieve long-term sustainability. More explicitly, Duthler and Dhanesh (2018) state that CSR is synonymous with sustainability.

Several studies have proven that CSR has a significant positive effect on business sustainability. Strand et al. (2015), in their research in Scandinavia, found that CSR had a significant positive effect on business sustainability. Similar results were also found in research conducted by Ngai et al (2018), where CSR had a significant positive effect on business sustainability in gas companies in China. Based on this argument, the following research hypothesis was built:

Hypothesis 1: CSR has a significant positive effect on business sustainability.

\section{Customer Trust}

Trust is very important in every aspect of social life (Gucel et al., 2012). Customer trust in a product or in the company itself is also important for the sustainability of the company. Consumers who have high confidence in a product tend to make repeated purchases and recommend the product to others, cultivating a strong relationship between company and consumer. This aligns with $\mathrm{Wu}$ et al. (2010): trust is an important factor in achieving a successful marketing relationship. This is further reinforced by Upamannyu et al. (2015), which states that increasing customer trust can lead to higher company profitability and, thus, sustainable growth. Rousseau et al. (1998) and Singh and Sirdeshmukh (2000) stated that customer trust is very important to build and maintain such relationships long term. This statement is in line with the results of Yu et al. (2018), which demonstrated that customer trust has a significant positive effect on business sustainability. Based on these arguments, the following research hypothesis was built:

Hypothesis 2: Customer trust has a significant positive effect on business sustainability.

Properly implemented CSR can lead to increases in customer trust (Vlachos et al., 2009). Many companies try to implement CSR to attract public trust, especially that of customers (Azmat \& Ha, 2013). The results of the research of Swaen and Chumpitaz (2008) and Choi and La (2013) found that CSR significantly positively affects customer trust. The same results were also found in research conducted by Kang and Hustvedt (2014): CSR significantly positively affects customer trust and attitudes towards the company. Research by Cegliński and Wiśniewska (2016) and Jalilvand et al. (2017) also found that CSR affects customer trust in a significantly positive manner. Referring to the findings of the research results, the following research hypothesis was built:

Hypothesis 3: Customer trust is positive significantly influenced by CSR.

\section{Customer Loyalty}

In general, customer loyalty means the intention to repeatedly purchase a company's products or services (Khan, 2013). According to Markovic et al. (2018), customer loyalty is a customer's intention to repurchase products and services as well as make referrals to other people. Gremler and Brown (1999) divide customer loyalty into three different categories: behavioral, intentional, and emotional. Krumay and Brandtweiner (2010) 
revealed that customer loyalty is one of the key factors in the success of a company. The same thing was expressed by Khadka and Maharjan (2017): customer loyalty is one of the keys to a company's successes and profits in the long run. Utami (2015) stated that customer loyalty can create a competitive advantage and increase market share and profit in the long term. In addition, customer loyalty plays an important role in ensuring a competitive advantage as well as retaining existing customers rather than acquiring new ones (Roy, 2011). Ayodele and Esiti (2016) explicitly stated that customer loyalty can increase a company's competitive advantage, which in-turn gives it potential to continue to grow sustainably. Based on these arguments, the following research hypothesis was built:

Hypothesis 4: Customer loyalty has a significant positive effect on business sustainability.

The customer loyalty a company or product has garnered can also be determined by its levels of customer trust. Customer trust is thus considered a predictor of customer loyalty (Bibb \& Kourdi, 2007; Chaudhuri \& Holbrook, 2001; Gul, 2014; Hsu, 2008; Liang \& Wang, 2007). Ndubisi (2007) and Taylor et al. (2004) also state that trust is an important factor in building company-customer relationships and ultimately fostering customer loyalty. Better customer trust leads to better attitudes and loyalty (Moreira \& Silva, 2015). This argument is in line with the research results of Sarwar et al. (2012). Ayodele and Esiti (2016) shows that trust has a significant positive effect on customer loyalty. Other studies have found that customer trust in a company greatly influences the repurchasing of that company's products (Chiu et al., 2008; Qureshi et al., 2009; Upamannyu et al., 2015). Utami (2015) found that customer trust has a significant positive effect on customer loyalty. Based on this argument, the following research hypothesis was built:

Hypothesis 5: Customer loyalty is positive significantly influenced by customer trust.

Besides being influenced by customer trust, customer loyalty can also be influenced by CSR. Vlachos et al. (2009), in their research, found that direct CSR has a significant positive effect on customer loyalty. The same conclusion was drawn from research conducted by Choi and La (2013). More explicitly, CSR is considered a key variable in restoring customer loyalty. The results of research by Azmat and $\mathrm{Ha}$ (2013) found that CSR can create a positive image and reputation, which in-turn generates customer loyalty. This statement is supported by research conducted by Diallo and Lambey-Checchin (2016) and Al-Abdallah and Ahmed (2018) in Qatar, where CSR activities were found to have a direct and significant positive effect on customer loyalty. This finding is also supported by the research results of Afridi et al. (2018) who found that CSR has a significant positive effect on customer loyalty. Al-Ghamdi and Badawi (2019) explicitly stated that corporate CSR has a strong and positive influence on customer loyalty. Based on the findings of the study, the following research hypothesis was built:

Hypothesis 6: Customer loyalty is significantly positively influenced by CSR. 
Many previous studies have concluded that CSR significantly affects customer trust (Cegliński \& Wiśniewska, 2016; Choi \& La, 2013; Jalilvand et al., 2017; Kang \& Hustvedt, 2014; Swaen \& Chumpitaz, 2008). In addition, it has been found that the relationship between customer trust and business sustainability is significant (Rousseau, et al., 1998; Singh \& Sirdeshmukh, 2000; Upamannyu et al., 2015; Wu et al., 2010; Yu et al., 2018). Based on these findings and drawing from Baron and Kenny (1987), it can be said that the customer has mediating potential in the relationship between CSR and business sustainability. Referring to these findings, the following research hypothesis was built:

Hypothesis 7: Customer trust is significantly positive as a mediator in the relationship between CSR and business sustainability.

Many previous studies have shown that CSR has a significant effect on customer loyalty (Al-Abdallah \& Ahmed, 2018; Al-Ghamdi \& Badawi, 2019; Afridi et al., 2018; Azmat \& Ha, 2013; Choi \& La, 2013; Diallo \& Lambey-Checchin, 2016; Vlachos et al., 2009). Likewise, customer loyalty can affect business sustainability (Ayodele \& Esiti, 2016; Khadka \& Maharjan, 2017; Krumay \& Brandtweiner, 2010; Roy, 2011; Utami, 2015). Based on these findings, and considering the concept of Baron \& Kenny (1987), it can be stated that customer loyalty can act as a mediator in the relationship between CSR and business sustainability. Based on the results of the study, the following research hypothesis was built:

Hypothesis 8: Customer loyalty is positive significantly as a mediator in the relationship between CSR and business sustainability.

As stated in building Hypothesis 3, CSR has a significant effect on customer trust (Cegliński \& Wiśniewska, 2016; Choi \& La, 2013; Jalilvand et al., 2017; Kang \& Hustvedt, 2014; Swaen \& Chumpitaz, 2008). Hypothesis 5 is based on the idea that customer trust also has a significant effect on customer loyalty (Ayodele \& Esiti, 2016; Chiu et al., 2008; Qureshi et al., 2009; Sarwar et al., 2012; Upamannyu et al., 2015). At the same time, as shown in Hypothesis 4, customer loyalty also significantly affects business sustainability (Ayodele \& Esiti, 2016; Khadka \& Maharjan, 2017; Krumay \& Brandtweiner, 2010; Roy, 2011; Utami, 2015). Referring to these findings and based on the concept of Baron and Kenny (1987), it can be argued that customer trust and customer loyalty together act as mediators in the relationship between corporate social sustainability and business sustainability. Thus, the following research hypothesis was built:

Hypothesis 9: Customer trust and customer loyalty together are positive significant as a mediator on CSR towards business sustainability. 


\section{Research Concept Framework}

The research concept framework is illustrated in Figure 1.

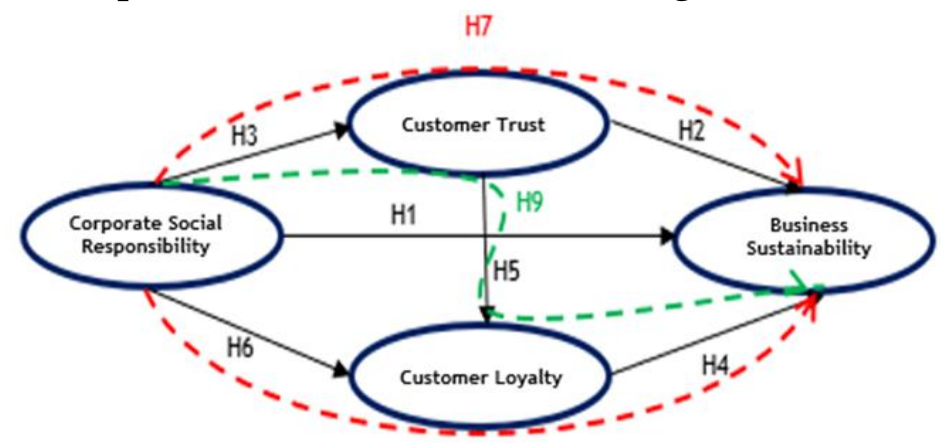

$\mathrm{H} 8$

Figure 1. Concept Framework of the Relationship between CSR, Customer Trust, Customer Loyalty, and Business Sustainability

\section{METHOD}

\section{Design, Population, and Research Samples}

This research was designed as a quantitative study to confirm the relationship between CSR, customer trust, customer loyalty, and business sustainability at Rural Banks in Bali, Indonesia. The total number of banks studied was 134, spread across 9 regencies/cities in Bali. The number of Rural Banks used as research samples was determined by the Slovin formula, with a precision of $5 \%$. The results of this calculation were as follows:

$\mathrm{n}=\mathrm{N} /(1+\mathrm{Ne} 2)$

$\mathrm{n}=134 /\{1+(134 \times 0.052)\}$

$\mathrm{n}=100.37$ (rounded to 100 )

The number proportions of Rural Banks in Bali and research respondents in each regency were determined using the proportionate random sampling method, and are shown in Table 1.

Table 1. Distribution of the Number of Rural Banks by Regency in Bali Year, 2019

\begin{tabular}{llcc}
\hline No & District & Number of Banks & Sample \\
\hline 1 & Badung & 49 & 37 \\
2 & Bangli & 3 & 2 \\
3 & Buleleng & 6 & 4 \\
4 & Gianyar & 26 & 19 \\
5 & Jembrana & 1 & 1 \\
6 & Karangasem & 4 & 3 \\
7 & Klungkung & 5 & 4 \\
8 & Tabanan & 19 & 14 \\
9 & Denpasar & 21 & 16 \\
\multicolumn{2}{c}{ Total } & 134 & 100 \\
\hline
\end{tabular}




\section{Data Analysis Technique}

The validity and reliability testing phase:

The data validity test was conducted through convergent validity and discriminant validity. Convergent validity testing was based on the outer loading coefficient, where a set of data is declared valid if the coefficient is 0.50 or more $(>0.50)$, and significant at a p-value of 0.05 (Chin, 1998). Testing the validity of data based on discriminant validity was shown by comparing the root value of Average Variance Extracted (VAVE) with the correlation value between variables. The AVE coefficient must be greater than 0.50 (Bagozzi \& Yi, 1988). Meanwhile, reliability testing was based on Cronbach's Alpha and Composite Reliability coefficients. It is said to be reliable if the data set has a greater Cronbach's Alpha and Composite Reliability coefficient than 0.70 (Hair et al., 2010).

Model accuracy testing phase:

The testing of the accuracy of the model was conducted through the R-square coefficient $\left(\mathrm{R}^{2}\right)$, Q-Square Predictive Relevance $\left(\mathrm{Q}^{2}\right)$, and Goodness of Fit (GoF).

Hypothesis testing stage:

Hypotheses were accepted if the p-value of the path coefficient was less than 0.05

\section{FINDING AND DISCUSSION}

\section{Validity and Reliability}

The results of data analysis carried out with the SmartPLS 3.3.2 program (the value of the outer loading of each indicator) are shown in Table 2.

Table 2. Validity and Reliability

\begin{tabular}{llccc}
\hline \multirow{2}{*}{ Variables } & \multicolumn{1}{c}{ Indicators } & $\begin{array}{c}\text { Outer loading } \\
\text { Coef. }\end{array}$ & $\begin{array}{c}\text { p- } \\
\text { value }\end{array}$ & Information \\
\hline \multirow{3}{*}{ CSR } & Economic & 0.930 & 0.000 & valid \\
& Social & 0.963 & 0.000 & valid \\
& Environment & 0.910 & 0.000 & valid \\
& Relationships between & 0.889 & 0.000 & valid \\
& employees & 0.879 & 0.000 & valid \\
& Understanding of work & 0.911 & 0.000 & valid \\
& Openness of & 0.870 & 0.000 & valid \\
Customer Loyalty & Communication & 0.976 & 0.000 & valid \\
& Work competence & 0.984 & 0.000 & valid \\
& Buyback & 0.949 & 0.000 & valid \\
& Recommended to others & 0.840 & 0.000 & valid \\
Business & Strategy & 0.879 & 0.000 & valid \\
Sustainability & Financial & 0.894 & 0.000 & valid \\
& Customer & 0.926 & 0.000 & valid \\
& Product & 0.933 & 0.000 & valid \\
& Governance & 0.922 & 0.000 & valid \\
\hline
\end{tabular}


Table 2 demonstrates that all variable indicators were convergent valid because they had an outer loading coefficient greater than 0.50 and significant. The discriminant validity test is shown in Table 3 .

Tabel 3. Discriminant Validity

\begin{tabular}{lccccc}
\hline Variables & AVE/VAVE & CSR & $\begin{array}{c}\text { Customer } \\
\text { Trust }\end{array}$ & $\begin{array}{c}\text { Customer } \\
\text { Loyalty }\end{array}$ & $\begin{array}{c}\text { Business } \\
\text { Sustainability }\end{array}$ \\
\hline CSR & $0.873 / 0.934$ & $\mathbf{0 . 9 3 4}$ & & & \\
Customer Trust & $0.793 / 0.891$ & 0.808 & $\mathbf{0 . 8 9 1}$ & & \\
$\begin{array}{l}\text { Customer } \\
\text { Loyalty }\end{array}$ & $0.943 / 0.971$ & 0.700 & 0.845 & $\mathbf{0 . 9 7 1}$ & \\
$\begin{array}{l}\text { Business } \\
\text { Sustainability }\end{array}$ & $0.810 / 0.900$ & 0.691 & 0.788 & 0.894 & $\mathbf{0 . 9 0 0}$ \\
\hline
\end{tabular}

Table 3 shows that all research variables were discriminantly valid, indicated by the value of the correlations between variables being greater than the root value of AVE.

Finally, the research variable reliability testing, indicated by the coefficient of Cronbach's Alpha and Composite Reliability, is shown in Table 4.

Table 4. Cronbach's Alpha and Composite Reliability

\begin{tabular}{lccc}
\hline Variables & Cronbach's Alpha & Composite Reliability & Information \\
\hline CSR & 0.927 & 0.962 & Reliable \\
Customer Trust & 0.913 & 0.939 & Reliable \\
Customer Loyalty & 0.970 & 0.980 & Reliable \\
Business Sustainability & 0.953 & 0.962 & Reliable \\
\hline
\end{tabular}

Table 4 shows that all research variables were reliable, indicated by the coefficient of Cronbach's Alpha and Composite Reliability being greater than 0.70. Validity and reliability testing demonstrated that all research data were valid and reliable.

\section{Model Accuracy Test}

Testing the accuracy of the research model was carried out through the R-Square coefficient $\left(\mathrm{R}^{2}\right)$, Q-Square Predictive Relevance $\left(\mathrm{Q}^{2}\right)$, and Goodness of Fit (GoF). The analysis results represented in Table 5 show the values of $\mathrm{R}^{2}$.

Table 5. R-Square $\left(\mathrm{R}^{2}\right)$ Coefficient

\begin{tabular}{lcc}
\hline Dependent Variables & R-Square $\left(\mathbf{R}^{2}\right)$ & Level \\
\hline Customer Trust & 0.652 & Large \\
Customer Loyalty & 0.709 & Large \\
Business Sustainability & 0.809 & Large \\
\hline
\end{tabular}

Table 5 shows the results of the analysis of the effect of CSR on customer trust. An $\mathrm{R}^{2}$ value of 0.652 means that $65.2 \%$ of customer trust was influenced by CSR, and the rest was influenced by another factor. The effect of CSR and customer trust on customer loyalty was indicated by an $\mathrm{R}^{2}$ value of 0.709 , which means that $70.9 \%$ of customer loyalty was influenced by customer trust and CSR, and the rest was influenced by another factor. Meanwhile, $80.9 \%$ of business sustainability was influenced by CSR, customer 
trust, and customer loyalty; the rest were influenced by other factors not included in this research model. This result, through the value of $\mathrm{R}^{2}$, shows the influence of CSR, customer trust, and customer loyalty on business sustainability. Based on Cohen's (1988) criteria for the strength and weakness of influence between variables, it can be stated that this research model had a high degree of accuracy.

Evaluation of fit models based on $\mathrm{Q}^{2}$ Predictive Relevance were calculated with the following formulations:

$$
\begin{aligned}
& \mathrm{Q} 2=1-\left\{\left(1-\mathrm{R}^{2}\right)\left(1-\mathrm{R}^{2}{ }_{2}\right)\left(1-\mathrm{R}^{2}{ }_{3}\right)\right\} \\
& \mathrm{Q} 2=1-\{(1-0.652)(1-0.709)(1-0.809)\} \\
& \mathrm{Q} 2=0.9807
\end{aligned}
$$

Based on the results of the Predictive Relevance $\mathrm{Q}^{2}$ calculation, it can be explained that the research model was able to provide predictive accuracy of $98.07 \%$ (large), while $1.93 \%$ of other factors were not examined. That is, according to the value of $\mathrm{Q}^{2}$, the model had a large degree of accuracy (Chin, 1998).

Evaluation of the accuracy of the research model, based on the Goodness of Fit criteria, was calculated using the following formulation:

$\mathrm{GoF}=\mathrm{V}$ (average AVE $\mathrm{x}$ average $\left.\mathrm{R}^{2}\right)$

$\mathrm{GoF}=\mathrm{V}\{(0.8413) \times(0.7233)\}$

$\mathrm{GoF}=0.7801$ (large)

Based on the results of the GoF calculation, the model had a level of accuracy of 0.7801 (classified as large according to Akter et al., 2011). Based on the 3 accuracy test results, it can be concluded that the model had a great degree of accuracy, therefore its use in the hypothesis testing process was justified.

\section{Hypothesis Testing}

The research hypothesis testing was based on the results of analysis by the SmartPLS 3.3.2 program and the modified SmartPLS analysis results table (displayed in Figure 2 and Table 6, respectively).

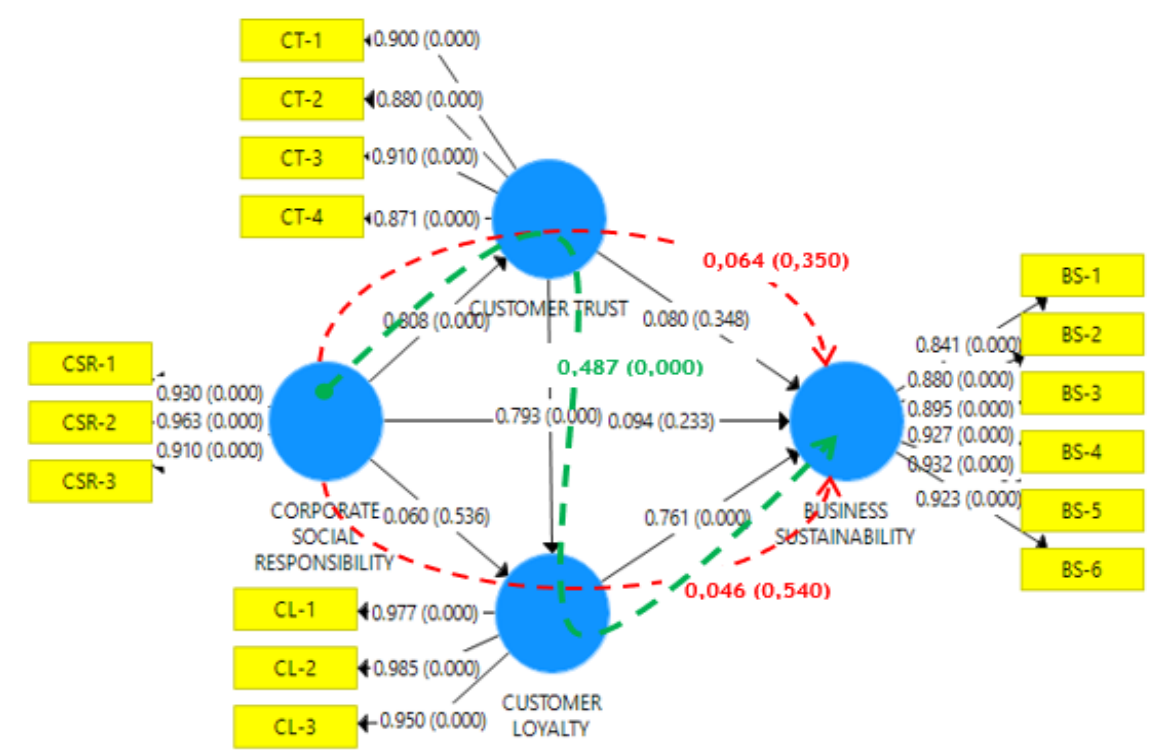

Figure 2. SmartPLS 3.3.2 analysis results (modified) 
Table 6. Path Coefficient

\begin{tabular}{|c|c|c|c|c|c|c|c|}
\hline \multirow{2}{*}{ Hypothesis } & & \multicolumn{3}{|c|}{ Correlation } & \multirow{2}{*}{$\begin{array}{c}\text { Path } \\
\text { Coefficient }\end{array}$} & \multirow{2}{*}{\multicolumn{2}{|c|}{$\begin{array}{c}\text { p- } \\
\text { t Value }\end{array}$}} \\
\hline & Independent & Med & iation & Dependent & & & \\
\hline $\begin{array}{l}\text { Hypothesis } \\
1\end{array}$ & CSR & & & $\begin{array}{l}\text { Business } \\
\text { Sustainability }\end{array}$ & 0.094 & 0.233 & $\begin{array}{l}\text { No } \\
\text { significant }\end{array}$ \\
\hline $\begin{array}{l}\text { Hypothesis } \\
2\end{array}$ & & $\begin{array}{l}\text { Custome } \\
\text { Trust }\end{array}$ & & $\begin{array}{l}\text { Business } \\
\text { Sustainability }\end{array}$ & 0.080 & 0.348 & $\begin{array}{l}\text { No } \\
\text { significant }\end{array}$ \\
\hline $\begin{array}{l}\text { Hypothesis } \\
3\end{array}$ & CSR & $\begin{array}{l}\text { Custome } \\
\text { Trust }\end{array}$ & & & 0.808 & 0.000 & significant \\
\hline Hypothesis & & & $\begin{array}{l}\text { Customer } \\
\text { Loyalty }\end{array}$ & $\begin{array}{l}\text { Bus } \\
\text { Sust }\end{array}$ & 0.761 & 0.000 & significant \\
\hline Нурс & & Custome & Customer & & 079 & 00 & $i \sigma$ \\
\hline 5 & & Trust & Loyalty & & 0.193 & 0.0 & IgI \\
\hline $\begin{array}{l}\text { Hypothesis } \\
6\end{array}$ & CSR & & $\begin{array}{l}\text { Customer } \\
\text { Loyalty }\end{array}$ & & 0.060 & 0.536 & $\begin{array}{l}\text { No } \\
\text { significant }\end{array}$ \\
\hline $\begin{array}{l}\text { Hypothesis } \\
7\end{array}$ & CSR & $\begin{array}{l}\text { Custome } \\
\text { Trust }\end{array}$ & & ability & 0.064 & 0.350 & $\begin{array}{l}\text { No } \\
\text { significant }\end{array}$ \\
\hline $\begin{array}{l}\text { Hypothesis } \\
8\end{array}$ & CSR & & $\begin{array}{l}\text { Customer } \\
\text { Loyalty }\end{array}$ & $\begin{array}{l}\text { Business } \\
\text { Sustainability }\end{array}$ & 0.046 & 0.540 & $\begin{array}{l}\text { No } \\
\text { significant }\end{array}$ \\
\hline $\begin{array}{l}\text { Hypothesis } \\
9\end{array}$ & CSR & $\begin{array}{l}\text { Custom } \\
\text { Trust }\end{array}$ & $\begin{array}{l}\text { Customer } \\
\text { Loyalty }\end{array}$ & $\begin{array}{l}\text { Business } \\
\text { Sustainability }\end{array}$ & 0.487 & 0.000 & significant \\
\hline
\end{tabular}

Based on Figure 2 and Table 6, it can be explained that corporate social sustainability had no significant effect on customer loyalty and business sustainability, because the p-value of each was greater than 0.05. Thus, Hypothesis 1 and Hypothesis 6 were rejected. Likewise, the effect of customer trust on business sustainability was not significant because the p-value was greater than 0.05 , so Hypothesis 2 was also rejected. The indirect effect of CSR on business sustainability through customer trust and customer loyalty was also insignificant because the p-value was greater than 0.05 , and so Hypothesis 7 and Hypothesis 8 were rejected. Of the 9 hypotheses proposed, only 4 hypotheses were accepted, namely Hypothesis 3 (effect of CSR on customer trust), Hypothesis 4 (effect of customer loyalty on business sustainability), Hypothesis 5 (effect of customer trust on customer loyalty), and Hypothesis 9 (indirect effect of CSR on business sustainability through customer trust and customer loyalty).

\section{CONCLUSION}

The results of the study found that business sustainability is a significant factor affecting customer loyalty. This finding is in line with the statements of Krumay and Brandtweiner (2010) and Khadka and Maharjan (2017): customer loyalty is the key to company success and profits in the long term. Utami concluded similarly, stating that customer loyalty can create competitive advantages, increase market share, and provide benefits in the long term. Ayodele and Esiti (2016) share this view; that loyalty can increase a company's competitive advantage and foster great potential for the continuation of sustainable growth. The results of this study are in line with the results of research by 
Wong et al. (2019), who found that customer loyalty has a significant positive effect on business sustainability.

The results also found that customer trust and customer loyalty together act as a full mediator in the relationship between CSR and business sustainability. These findings prove that the combination of customer trust and customer loyalty can be a strong mediator in rendering the relationship between CSR and business sustainability significant. Azmat and Ha (2013) also state that higher customer loyalty and trust are recognized as important for businesses to gain a unique profit advantage in the market. A similar statement was also expressed by Ong and Zien (2015): customer trust and loyalty are very important to ensure sustainable income and profits for business sustainability.

Based on the results of this study, the researcher recommends that although it does not directly have a significant effect on business sustainability, it is important to constantly aim to increase and maintain customer trust. At the same time, companies should increase efforts to maintain and increase customer loyalty, as the results of this study clearly show that the combination of trust and loyalty is able to significantly support business sustainability.

\section{Limitations and Future Research}

This study was limited to only a sample of Rural Banks in Bali, such that it cannot be used to generalize across all Rural Banks in Bali; research still needs to develop outside of this area. Similarly, the variables included in the research model were limited to CSR, customer trust, and customer loyalty in relation to business sustainability. Business sustainability, especially in banking, is strongly influenced by internal and external factors. Therefore, future research could consider including more relevant variables in a research model, as well as expanding the scope of the research area; these two developments are expected to provide more accurate information.

\section{REFERENCES}

Afridi, S. A., Gul, S., Haider, M., \& Batool, S. (2018). Mediating effect of customers' trust between the association of corporate social responsibility and customers' loyalty. Pakistan Journal of Commerce and Social Sciences (PJCSS), 12(1), 214-228. http://www.jespk.net/publications/422.pdf

Akter, S., D'Ambra, J. and Ray, P. (2011), An evaluation of PLS based complex models: the roles of power analysis, predictive relevance and GoF index, Proceedings of the Seventeenth Americas Conference on Information Systems, Detroit, Michigan August 4th-7th 2011. https: $/ /$ ro.uow.edu.au/cgi/viewcontent.cgi?article $=4186 \&$ context $=$ commpapers

Al-Abdallah, G. M., \& Ahmed, R. S. (2018). The impact of corporate social responsibility on customer loyalty in the Qatari telecommunication sector. Journal of Business and Retail Management Research, 13(01). https://jbrmr.com/cdn/article file/2018-10-03-15-34-02-PM.pdf

Al-Ghamdi, S. A. A., \& Badawi, N. S. (2019). Do corporate social responsibility activities enhance customer satisfaction and customer loyalty? Evidence from the Saudi 
banking sector. Cogent Business \& Management, 6(1), 1662932. https://www.econstor.eu/bitstream/10419/206232/1/23311975.2019.1662932.p $\underline{\mathrm{df}}$

Aslam, W., Hussain, A., Farhat, K., \& Arif, I. (2020). Underlying Factors Influencing Consumers' Trust and Loyalty in E-commerce. Business Perspectives and Research, 8(2), 186-204. https://sci-hub.tw/10.1177/2278533719887451

Ayodele, A. A., \& Esiti, B. G. (2016). Predictive Indicators Of Customer Loyalty In The Nigerian Gsm Market. British Journal of Marketing Studies, 4(7). https://papers.ssrn.com/sol3/papers.cfm?abstract $\mathrm{id}=3118705$

Azmat, F., \& Ha, H. (2013). Corporate social responsibility, customer trust, and loyaltyperspectives from a developing country. Thunderbird International Business Review, $55(3)$

253-270. https://onlinelibrary.wiley.com/doi/abs/10.1002/tie.21542

Bagozzi, R. P., \& Yi, Y. (1988). On the evaluation of structural equation models. Journal of the academy of marketing science, 16(1), 74-94. https://link.springer.com/article/10.1007/BF02723327

Baron, R.M., and Kenny, D.A. (1987), The moderator-mediator variable distinction in social psychological research: conceptual, strategic, and statistical considerations. Journal of Personality and Social Psychology, Vol. 103, No. 6, pp. 1173-1182. https://psycnet.apa.org/buy/1987-13085-001

Behringer, K., Szegedi, K. (2016). The Role Of CSR In Achieving Sustainable Development-Theoretical Approach. European Scientific Journal, 12(22), 10-25. http://eujournal.org/index.php/esj/article/view/7936

Bibb, S., and Kourdi, J. (2007). A Question of Trust. London: Marshall Cavendish

Brilliant, M. A., \& Achyar, A. (2013). The impact of satisfaction and trust on loyalty of ecommerce customers. ASEAN Marketing Journal. Vol.V - No. 1. 51-58. http://perpustakaan.unitomo.ac.id/repository/2175-4020-1-SM.pdf

Carroll, A. B. (1979). A three-dimensional conceptual model of corporate performance. Academy of Management Review,4(4), 497-505. https://journals.aom.org/doi/abs/10.5465/amr.1979.4498296

Cegliński, P., \& Wiśniewska, A. (2016). CSR as a source of competitive advantage: The case study of Polpharma group. Journal of Corporate Responsibility and Leadership, $3(4), \quad 9-25$. https://apcz.umk.pl/czasopisma/index.php/JCRL/article/view/JCRL.2016.02 $\underline{0}$

Chaudhuri, A., \& Holbrook, M. B. (2001). The chain of effects from brand trust and brand affect to brand performance: the role of brand loyalty. Journal of Marketing, 65(2), https://journals.sagepub.com/doi/abs/10.1509/jmkg.65.2.81.18255

81-93.

Chin, W.W. (1998), The Partial Least Squares Approach to Structural Equation Modeling, In Marcoulides, G.A., editor. Modern Method for Business Research, Mahwah, New Jersey: Lawrence Erlbaum Associates, London

Chiu, C. M., Lin, H. Y., Sun, S. Y., \& Hsu, M. H. (2008). Understanding customers' loyalty intentions towards online shopping: an integration of technology acceptance model and fairness theory. Behaviour \& Information Technology, 
28(4), 347-360.

https://www.tandfonline.com/doi/abs/10.1080/01449290801892492

Choi, B., \& La, S. (2013). The impact of corporate social responsibility (CSR) and customer trust on the restoration of loyalty after service failure and recovery. Journal of Services Marketing, 27(3), 223-233. https://doi:10.1108/08876041311330717

Cohen, J. (1988), Statistical power analysis for the behavioral science, Second Edition, Hilsdale, New Jersey: Lawrence Erlbaum Associates

Diallo, M. F., \& Lambey-Checchin, C. (2016). Relationships between CSR and customer loyalty: what lessons for retailers?. https://hal.archives-ouvertes.fr/hal$\underline{01349979 /}$

Duthler, G.; Dhanesh, S. (2018). The role of corporate social responsibility (CSR) and internal CSR communication in predicting employee engagement: Perspectives from the United Arab Emirates (UAE). Public Relat., in press.

Fontaine, M. (2013). Corporate social responsibility and sustainability: the new bottom line?. International Journal of Business and Social Science, 4(4). http://www.mktgsensei.com/AMAE/Vision\%20and\%20Mission/Corproate $\% 2$ 0Social\%20Responsibility\%20Fontaine.pdf

Gonzalez F.M., Ávila L.G., Beltrán A.A., Hernández C. (2013). Measuring and Evaluating Business Sustainability: Development and Application of Corporate Index of Sustainability Performance. EcoProduction, 33-61. https://link.springer.com/chapter/10.1007/978-3-642-32081-1_3

Gremler, D. \& Brown, S. 1999. The Loyalty Ripple Effect: Appreciating the full value of customers. International Journal of Service Industry Management, Volume 10, Issue 3, pp 271-28. https://sci-hub.tw/10.1108/09564239910276872

Grigoris, G. (2016). The challenges of corporate social responsibility assessment methodologies. https://www.ijeba.com/documents/papers/2016_1_p3.pdf

Gucel C. Tokmak I, Turgut H. (2012). The Relationship of The Ethical Leadership Among the Organizational Trust, Affective Commitment, and Job Satisfaction: Case Study of a University. International Journal of Social Sciences and Humanity Studies Vol 4, No 2, pp. 101-110

Gul. R. (2014). The Relationship between Reputation, Customer Satisfaction, Trust, and Loyalty, Journal of Public Administration and Governance, 4(3). http://citeseerx.ist.psu.edu/viewdoc/download?doi=10.1.1.996.6819\&rep=rep1 \&type $=\mathrm{pdf}$

Hair, J.F., Black, W.C., Babin, B.J. and Anderson, R.E. (2010), Multivariate Data Analysis, Seventh Edition, Pearson Prentice Hall

Hossain, M. S., Hasan, R., Kabir, S. B., Mahbub, N., \& Zayed, N. M. (2019). Customer participation, value, satisfaction, trust, and loyalty: an interactive and collaborative strategic action. Academy of Strategic Management Journal, 18(3), 1-7. $\quad$ https://www.abacademies.org/articles/Customer-participation-valuesatisfaction-trust-and-loyalty-an-interactive-and-collaborative-1939-6104-18-3$\underline{386 . p d f}$

Hsu, S.H. (2008). Developing an index for online customer satisfaction: adaptation of American Customer Satisfaction Index. Expert Systems with Applications, 34(4), 
3033-3042.

https://www.sciencedirect.com/science/article/abs/pii/S0957417407002333

Jalilvand, M. R., Vosta, L. N., Mahyari, H. K., \& Pool, J. K. (2017). Social responsibility influence on customer trust in hotels: mediating effects of reputation and word-ofmouth.

Tourism

Review.

https://www.emerald.com/insight/content/doi/10.1108/TR-09-2016$\underline{0037 / \text { full/html }}$

Kang, J., \& Hustvedt, G. (2014). Building trust between consumers and corporations: The role of consumer perceptions of transparency and social responsibility. Journal of Business Ethics, 125(2),

https://link.springer.com/article/10.1007/s10551-015-2690-5

Khadka, K., \& Maharjan, S. (2017). Customer satisfaction and customer loyalty: Case trivsel städtjänster (trivsel siivouspalvelut). https://core.ac.uk/download/pdf/161421179.pdf

Khan, M. T. (2013). Customer loyalty: Concept \& definition (a review). International Journal of Information, Business, and Management, 5(3), 168. https://www.academia.edu/34440985/Customers Loyalty Concept and Defini tion A Review

Kitthananan, A. (2010). Creating business and social value: the Asian way to integrate CSR into business strategies. Studies in Trade and Investment, 68. https://ideas.repec.org/b/unt/ecbook/indpub2565.html

Krumay, B., \& Brandtweiner, R. (2010). Are Customer Service Offerings Influencing ELoyalty? A Graphical Chain Model Approach in the Austrian Mobile Phone. https://www.academia.edu/406027/Are_Customer_Service_Offerings_Influenci ng E Loyalty A Graphical Chain Model Approach In the Austrian Mobile $\underline{\text { Phone }}$

Leninkumar, V. (2017). The relationship between customer satisfaction and customer trust on customer loyalty. International Journal of Academic Research in Business and Social Sciences, 7(4), 450-465. https://pdfs.semanticscholar.org/0a7a/f73f11987f25a76fdaadf8cdf468e9276150. pdf

Liang, C. J., \& Wang, W. H. (2007). The behavioral sequence of information education services industry in Taiwan: relationship bonding tactics, relationship quality, and behavioral loyalty. Measuring Business Excellence.

https://www.emerald.com/insight/content/doi/10.1108/13683040710752742/f $\underline{\mathrm{ull} / \mathrm{html}}$

Lu, J., Ren, L., Yao, S., Qiao, J., Mikalauskiene, A., \& Streimikis, J. (2020). Exploring the relationship between corporate social responsibility and firm competitiveness. Economic Research-Ekonomska Istraživanja, 33(1), 1621-1646. https://www.tandfonline.com/doi/full/10.1080/1331677X.2020.1761419

Málovics, G., Csigéné, N. N., \& Kraus, S. (2008). The role of corporate social responsibility in strong sustainability. The Journal of Socio-Economics, 37(3), 907-918. https://doi:10.1016/j.socec.2006.12.061

Markovic, S., Iglesias, O., Singh, J. J., \& Sierra, V. (2018). How does the perceived ethicality of corporate services brands influence loyalty and positive word-ofmouth? Analyzing the roles of empathy, affective commitment, and perceived 
quality. Journal of Business Ethics, 148(4), 721-740. https://doi.org/10.1007/s10551-015-2985-6

Moreira, A.C. \& Silva, P.M. 2015. The trust-commitment challenge in service qualityloyalty relationships. International Journal of Health Care Quality Assurance, Vol. 28, No. 3, pp. 253-266, https://doi.org/10.1108/IJHCQA-02-2014-0017

Mourougan S. (2015), Corporate Social Responsibility for sustainable business, IOSR Journal of Business and Management, Volume 17, Issue 5.Ver. I (May. 2015), PP 94-106 http://www.iosrjournals.org/iosr-jbm/papers/Vol17-issue5/Version1/L0175194106.pdf

Ndubisi, N. O. (2007). Relationship marketing and customer loyalty. Marketing intelligence \& planning. https://doi.org/10.1108/02634500710722425

Ngai, E. W. T., Law, C. C., Lo, C. W., Poon, J. K. L., \& Peng, S. (2018). Business sustainability and corporate social responsibility: case studies of three gas operators in China. International Journal of Production Research, 56(1-2), 660676. https://www.tandfonline.com/doi/abs/10.1080/00207543.2017.1387303

Nguyen, N., Leclerc, A., \& LeBlanc, G. (2013). The mediating role of customer trust on customer loyalty. Journal of Service Science and Management, Vol.6, No.1, pp. 96-109 https://www.scirp.org/html/10-9201524 28959.htm

Nur, H. (2012). The Effect Of Customer Satisfaction, Customer Trust On Customer Loyalty Of The Card Users Of PT. Indosat Tbk. In proceedings intl conf information system business competitiveness. https://core.ac.uk/download/pdf/11733089.pdf

Ong, C. H., \& Zien Yusoff, R. (2015). Brand experience, trust components, and customer loyalty: Sustainable Malaysian SME brands study. Asian Social Science, 11(26), 252-266. https://papers.ssrn.com/sol3/papers.cfm?abstract_id=2677333

Qureshi, I., Fang, Y., Ramsey, E., McCole, P., Ibbotson, P., \& Compeau, D. (2009). Understanding online customer repurchasing intention and the mediating role of trust-an empirical investigation in two developed countries. European Journal of Information Systems, $18(3)$, 205-222. https://orsociety.tandfonline.com/doi/abs/10.1057/ejis.2009.15

Rousseau, D. M., Sitkin, S. B., Burt, R. S., \& Camerer, C. (1998). Not so different after all: A cross-discipline view of trust. Academy of management review, 23(3), 393404. https://journals.aom.org/doi/abs/10.5465/AMR.1998.926617

Roy, S. (2011). Brand Loyalty Measurement A Framework. SCMS Journal of Indian Management, 8(2), 112. https://search.proquest.com/docview/897914175?pqorigsite $=$ gscholar\&fromopenview $=$ true

Sarmawa, I. W. G., Widyani, A. A. D., Sugianingrat, I. A. P. W., \& Martini, I. A. O. (2020). Ethical entrepreneurial leadership and organizational trust for organizational sustainability. Cogent Business \& Management, 7(1), 1818368.

Sarwar, M. Z., Abbasi, K. S., \& Pervaiz, S. (2012). The effect of customer trust on customer loyalty and customer retention: A moderating role of cause-related marketing. Global Journal of Management and Business Research, 12(6). https://www.journalofbusiness.org/index.php/GJMBR/article/view/685

Schaltegger, S., \& Burritt, R. (2005). Corporate sustainability (Doctoral dissertation, Edward Elgar). 
Setiawan, H., \& Sayuti, A. J. (2017). Effects of service quality, customer trust, and corporate image on customer satisfaction and loyalty: an assessment of travel agencies customer in South Sumatra Indonesia. IOSR Journal of Business and Management, 19(5), 31-40. https://pdfs.semanticscholar.org/7e01/10ca2dcc0c2ab03d0b696872ed8cf0c4635 $\underline{0 . p d f}$

Singh, J., \& Sirdeshmukh, D. (2000). Agency and trust mechanisms in consumer satisfaction and loyalty judgments. Journal of the Academy of Marketing Science, 28(1), https://journals.sagepub.com/doi/abs/10.1177/0092070300281014 150-167.

Strand, R., Freeman, R. E., \& Hockerts, K. (2015). Corporate social responsibility and sustainability in Scandinavia: An overview. Journal of Business Ethics, 127(1), 115. https://link.springer.com/article/10.1007/s10551-014-2224-6

Strenitzerová, M., \& Gaňa, J. (2018). Customer satisfaction and loyalty as a part of customer-based corporate sustainability in the sector of mobile communications services. Sustainability, 10(5), 1657. https://www.mdpi.com/2071$\underline{1050 / 10 / 5 / 1657}$

Swaen, V., \& Chumpitaz, R. C. (2008). Impact of corporate social responsibility on consumer trust. Recherche et Applications en Marketing (English Edition), 23(4), 7-34.

Szekely, F., \& Knirsch, M. (2005). Responsible leadership and corporate social responsibility:: Metrics for sustainable performance. European Management 23(6),

628-647. https://www.sciencedirect.com/science/article/abs/pii/S0263237305001131

Taoketao, E., Feng, T., Song, Y., \& Nie, Y. (2018). Does sustainability marketing strategy achieve payback profits? A signaling theory perspective. Corporate Social Responsibility and Environmental Management, 25(6), 1039-1049. https://onlinelibrary.wiley.com/doi/abs/10.1002/csr.1518

Taylor, S.A., Celuch, K., \& Goodwin, S. (2004). The Importance of Brand Equity to Customer Loyalty. The Journal of Product and Brand Management, 13(4), 217227. https://doi.org/10.1108/10610420410546934

Teodorescu, M., \& Ionescu, D. (2014). Corporate social responsibility-sustainability and profitability. International Letters of Social and Humanistic Sciences, 14, 50-58. https://www.ceeol.com/search/article-detail?id=72734

Trini, D., \& Salim, M. N. (2018). Customer Experience Marketing (CEM), Customer Satisfaction and Customer Trust Affects Customer Loyalty: A Study on Star Hotels in Jakarta Province. Business Management and Strategy, 9(2), 100-116. https://ideas.repec.org/a/mth/bmsmti/v9y2018i2p100-116.html

Upamannyu, N. K., Gulati, C., Chack, A., \& Kaur, G. (2015). The effect of customer trust on customer loyalty and repurchase intention: The moderating influence of perceived CSR. International Journal of Research in IT, Management and Engineering, $5(4)$, $1-31$. http://www.indusedu.org/pdfs/IJRIME/IJRIME 384 20219.pdf

Utami, S. (2015). The Influence Of Customersee Trust On Customer Loyalty. International journal of economics, commerce, and management, 3(7), 638-653. http://ijecm.co.uk/wp-content/uploads/2015/07/3743.pdf 
Vlachos, P. A., Tsamakos, A., Vrechopoulos, A. P., \& Avramidis, P. K. (2009). Corporate social responsibility: attributions, loyalty, and the mediating role of trust. Journal of the Academy of Marketing Science, 37(2), 170-180. https://doi.org/10.1007/s11747-008-0117-x

Widodo, A., \& Murwatiningsih, M. (2019). The Influence of Promotion and Trust on Customer Loyalty through Customer Satisfaction. Management Analysis Journal, $8(3)$, 265-274. https://journal.unnes.ac.id/sju/index.php/maj/article/view/33475

Wong, H. S., Wong, R. K., \& Leung, S. (2019). Enhancing Sustainability in Banking Industry: Factors Affecting Customer Loyalty. Academy of Accounting and Financial Studies Journal, 23(3), 1-12.

Wu, P. C., Yeh, G. Y. Y., \& Hsiao, C. R. (2010). The effect of store image and service quality on brand image and purchase intention for private label brands. Australasian Marketing Journal, 30-39. https://www.sciencedirect.com/science/article/abs/pii/S1441358210000844 